\title{
Mediasi Ukuran Perusahaan Antara Tax Avoidance dan Leverage Terhadap Cost of Debt
}

\author{
Artauli Angel Situmeang1, Harlyn L. Siagian² \\ 1,2 Universitas Advent Indonesia \\ Email: 1832005@unai.edu ${ }^{1}$
}

\section{ARTICLE INFO}

Article History:

Received: May 17th 2021

Accepted: June 6st 2021

Published: June $11^{\text {th }} 2021$

Keywords:

Tax Avoidance,

Leverage,

Ukuran Perusahaan,

Cost of Debt

\begin{abstract}
The purpose of this research was to determine and analyze the effect of tax avoidance and leverage on cost of debt with firm size as intervening variable. This research is quantitative and uses secondary data taken from annual reports of manufacturing companies in the non-cyclicals food and beverage sub-sector listed on Indonesia Stock Exchange (BEI) during the 2016-2019 period. The research method used is purposive sampling method with a population of 10 companies as the object of study over a period of 4 years and the sample used is 40 data. The analytical method used is descriptive statistic analysis, coefficient of correlation analysis, coefficient of determination analysis, classical assumption test, path analysis, $f$ test, $t$ test and multiple regression analysis assisted by using SPSS 24. The results of the analysis show that tax avoidance and leverage has no significant effect on firm size. Tax avoidance, leverage and firm size has significant effect on cost of debt. Indirectly, tax avoidance and leverage through firm size has no significant effect on cost of debt.
\end{abstract}

\section{Pendahuluan}

Saat ini hampir seluruh negara yang ada didunia ini menghadapi pandemi yaitu Covid-19 termasuk negara Indonesia. Akibat dari pandemi ini mempengaruhi banyak sektor khususnya sektor ekonomi. Banyak perusahaan-perusahaan mengalami kebuntuan sehingga menyebabkan kebangkrutan. Agar perusahaan tetap eksis atau beroperasi, maka perlu ditambah modal yaitu melalui pinjaman-pinjaman yang ditawarkan lembaga keuangan.

Meyer mengatakan dalam berita CNBC online (Jul, 2020), pandemi saat ini berpengaruh secara signifikan terhadap keuangan ratusan perusahaan global dunia. Dikabarkan pada tahun 2020 ini, sebanyak Rp. 14.000 triliun diduga akan menjadi cost of debt seluruh perusahaan yang ada di seluruh dunia untuk membantu masyarakat yang tingkat perekonomiannya sedang kritis akibat dampak dari pandemi ini dimana data ini telah ditinjau dari 900 perusahaan internasional. Maka hal ini akan berdampak pada utang perusahaan global yang mengalami peningkatan cost of debt sebesar $12 \%$ dari tahun-tahun sebelumnya. 
Pinjaman yang dilakukan oleh perusahaan, bisa untuk pembayaran utang yang jatuh tempo atau untuk menambah modal. Namun pinjaman tersebut akan menimbulkan biaya yang disebut dengan istilah cost of debt yang akan ditanggung oleh perusahaan. Cost of debt menurut Handini (2020) adalah "salah satu biaya modal utang yang perusahaan gunakan untuk mengoperasikan kegiatan perusahaannya yang dipinjam dari pihak luar". Dengan tingkat bunga yang diterima kreditur sebagai tingkat pengembalian yang diisyaratkan dan perusahaan akan dikatakan mengalami gulung tikar apabila tidak bisa mengembalikan cost of debt dengan tepat waktu. Disinilah diperlukan pengawasan dan pengendalian dalam mengelola utang.

Pengelolaan perusahaan terhadap utang dapat dilakukan dengan meningkatkan laba yang optimal. Agar laba dapat optimal, maka pendapatan dimaksimalkan dan beban pajak dapat ditekan seminim mungkin. Menurut Isroah (2013), tax avoidance merupakan "metode yang termasuk ke dalam perlawanan aktif dimana perusahaan berusaha untuk menghindari pajak yang bersifat legal." (hlm. 14). Terkait dengan penghindaran pajak di Indonesia pada tahun 2019 yang diliput dari Kontan (Yuniartha, 2019), Kementerian Keuangan mencatat penerimaan pajak pada perusahaan manufaktur turun sebanyak $16,2 \%$. Bahkan salah satu perusahaan manufaktur terbesar dunia diduga melakukan penghindaran pajak di enam negara, termasuk negara Indonesia senilai US\$ 700 juta sebagai upaya untuk mengalihkan keuntungan ke negara lain yang memiliki tarif pajak yang rendah karena perusahaan tersebut mengalami kerugian selama tujuh tahun berturut-turut (para 3).

Penggunaan utang atau dana pinjaman perlu ditingkatkan untuk potensi pengembalian yang maksimal. Menurut penelitian sebelumnya (Pratama \& Wiksuana, 2016), leverage dapat digunakan oleh perusahaan untuk mengukur seberapa besar pendanaan dan biaya modal utang yang dibutuhkan oleh perusahaan tersebut. Dalam hal ini leverage memiliki pengaruh terhadap cost of debt dalam memperoleh biaya modal utang untuk mendapatkan profit yang lebih banyak lagi (Suwardika \& Mustanda, 2017). Hasil penelitian yang dilakukan oleh peneliti lain (Lim, 2011) membuktikan bahwa leverage berpengaruh signifikan terhadap cost of debt.

Faktor lain yang mempengaruhi cost of debt yaitu ukuran perusahaan. Menurut Dewi dan Badjra (2017), "besarnya ukuran perusahaan mencerminkan seberapa besar profit, termasuk total penjualan". Peneliti terdahulu (Wardani \& Ruslim, 2020) menyatakan bahwa semakin luas ukuran suatu perusahaan, maka semakin besar pula biaya utang yang dibutuhkan sebagai sumber pendanaan. Hasil penelitian serupa (Ashkhabi \& Agustina, 2015), membuktikan bahwa ukuran perusahaan berpengaruh positif signifikan terhadap cost of debt.

Karena penelitian-penelitian terdahulu masih belum membuktikan keterkaitan yang konsisten antara pengaruh tax avoidance dan leverage terhadap cost of debt, maka peneliti menggunakan variabel ukuran perusahaan sebagai variabel mediasi yang mempengaruhi hubungan diantara variabel tax avoidance dan leverage terhadap cost of debt. Itulah mengapa, peneliti mengangkat judul "Mediasi Ukuran Perusahaan Antara Tax Avoidance Dan Leverage Terhadap Cost Of Debt". Penelitian ini dilakukan pada perusahaan manufaktur sektor industri consumer non-cyclicals subsektor makanan dan minuman yang terdaftar pada Bursa 
Efek Indonesia karena produk barang konsumsi merupakan kebutuhan pokok sehari-hari manusia. Oleh sebab itu, peneliti berasumsi bahwa perusahaan subsektor makanan dan minuman memiliki kondisi keuangan yang cukup stabil.

\section{Kajian Teori dan Telaah Literatur}

\section{Ukuran Perusahaan}

Ukuran perusahaan menurut Subroto (2014) adalah "suatu kapasitas dari besar kecilnya perusahaan yang dihitung dari total aset perusahaan" (hlm. 47). Didalam penelitian Rahmawati (2017), semakin besar ukuran dari suatu perusahaan, maka dapat dibuktikan bahwa perusahaan tersebut dapat mengelola asetnya dengan tepat (hlm. 64).

\section{Tax Avoidance}

Tax avoidance menurut Mahi (2016) adalah "sistem pengurusan pajak secara legal dalam ketidakinginan perusahaan terhadap pengenaan pajak yang sesuai dengan undang-undang yang berlaku" (hlm. 156). Penelitian terdahulu (Hidayat, 2018) mengukur tax avoidance dengan sejumlah kas yang digunakan untuk membayar pajak dibagi laba sebelum pajak.

\section{Leverage}

Leverage menurut Manik, Sianipar dan Yunanto (2015) adalah "skala pengukuran untuk menghitung seberapa besar modal utang yang digunakan oleh suatu perusahaan dalam membiayai kinerja dan operasional perusahaan tersebut" (hlm. 48). Dalam hal ini, rasio DER yang peneliti sebelumnya (Hidayat, 2018) pakai untuk menghitung biaya modal utang tersebut (hlm. 23). Semakin tinggi rasio leverage perusahaan tersebut, maka hal tersebut menandakan bahwa jumlah cost of debt juga besar (Ernawati \& Widyawati, 2015).

\section{Cost Of Debt}

Cost of debt menurut Cooper, Donald dan Schindler (2013) adalah "salah satu dari upaya perusahaan untuk mendanai kegiatan dan kinerja perusahaannya dengan cara mendapatkan modal utang sebagai sumber pendanaan secara eksternal dari pihak luar dengan jaminan pengembalian yang telah disepakati oleh dua pihak yang berjanji". Cost of debt menurut penelitian terdahulu (Fitriani, 2017) dapat dihitung dengan membagi beban bunga dalam jangka waktu satu tahun dibagi dengan jumlah rata-rata pinjaman jangka panjang dan jangka pendek yang berbunga selama tahun berjalan.

\section{Metode Penelitian}

\section{Desain Penelitian}

Pendekatan yang digunakan pada penelitian menggunakan pendekatan kuantitatif yang kemudian diolah hingga menghasilkan kesimpulan. Penelitian ini diharapkan memenuhi kaidah-kaidah yang diharapkan objektif, terukur, dan konkrit/empiris serta rasional dan sistematis. Penelitian ini mencoba menghubungkan hubungan kausal antara variabel dalam penelitian dan hipotesis penelitian. Dalam penelitian ini peneliti ingin mencari tahu bagaimana pengaruh variabel independen terhadap variabel dependen. 


\section{Populasi dan Sampel Penelitian}

Populasi dalam penelitian ini adalah perusahaan yang terdaftar pada Bursa Efek Indonesia (BEI). Perusahaan pada BEI dipilih oleh karena perusahaan ini bergerak di bidang pasar modal dan mereka menyediakan layanan informasi keuangan untuk dapat dianalisa oleh investor dan publik. Sedangkan sampel yang digunakan dalam penelitian ini adalah perusahaan manufaktur sektor industri consumer non-cyclicals subsektor makanan dan minuman yang terdaftar pada BEI dengan menggunakan kriteria tertentu. Teknik pemilihan sampel menggunakan teknik purposive sampling dimana sampel diambil dengan menggunakan kriteria tertentu yang ditetapkan sesuai tujuan penelitian. Adapun kriteria yang digunakan dalam penelitian ini adalah:

1. Perusahaan terdaftar di BEI tahun 2016-2019

2. Perusahaan merupakan perusahaan manufaktur sektor industri consumer non-cyclicals subsektor makanan dan minuman yang terdaftar di BEI tahun 2016-2019

3. Perusahaan yang dijadikan sampel adalah perusahaan yang tercatat ke dalam papan utama dari 38 perusahaan dan diperoleh sampel sebanyak 10 perusahaan dengan empat tahun pengamatan sehingga diperoleh data sampel sebanyak 40 data.

Tabel 1. Daftar Perusahaan Yang Dijadikan Sampel

\begin{tabular}{cll}
\hline No. & \multicolumn{1}{c}{$\begin{array}{c}\text { Kode } \\
\text { Perusahaan }\end{array}$} & \multicolumn{1}{c}{ Nama Perusahaan } \\
\hline 1. & BUDI & PT Budi Starch \& Sweetener Tbk \\
2. & CEKA & PT Wilmar Cahaya Indonesia Tbk \\
3. & CLEO & PT Sariguna Primatirta Tbk \\
4. & CPIN & PT Charoen Pokphand Indonesia Tbk \\
5. & DSFI & PT Dharma Samudera Fishing Industries Tbk \\
6. & DSNG & PT Dharma Satya Nusantara Tbk \\
7. & HOKI & PT Buyung Poetra Sembada Tbk \\
8. & ICBP & PT Indofood CBP Sukses Makmur Tbk \\
9. & MYOR & PT Mayora Indah Tbk \\
10. & ULTJ & PT Ultrajaya Milk Industry \& Trading \\
\hline
\end{tabular}

\section{Definisi Operasional dan Pengukurannya}

Penelitian ini menggunakan 4 variabel mencakup cost of debt sebagai variabel dependen serta tax avoidance, leverage dan ukuran perusahaan sebagai variabel independen. Skala pengukuran penelitian dengan menggunakan rasio keuangan.

\section{Ukuran Perusahaan}

Adapun penelitian ukuran perusahaan ini dilakukan dengan menghitung total aset yang dimiliki perusahaan tiap tahun (Lim, 2011).

$$
\text { Size }=\text { Ln total assets }
$$




\section{Tax Avoidance}

Adapun penelitian tax avoidance ini dilakukan dengan menghitung pembayaran pajak perusahaan terhadap laba sebelum pajak perusahaan. (Hanlon, Michelle \& Heitzman, 2010).

$$
\text { CETR }=\frac{\text { Total tax expenses }}{\text { Earning before taxes }}
$$

\section{Leverage}

Adapun penelitian leverage ini dilakukan dengan menghitung total kewajiban perusahaan terhadap total ekuitas perusahaan (Sartono, 2015).

$$
D E R=\frac{\text { Total Debt }}{\text { Total Equity }}
$$

\section{Cost Of Debt}

Adapun penelitian cost of debt ini dilakukan dengan menghitung beban bunga perusahaan terhadap rata-rata pinjaman jangka pendek dan jangka panjang perusahaan (Kholbadalov, 2012).

$$
C O D=\frac{\text { Interest expense for the year }}{\text { Average of short term and long term debt during the year }}
$$

\section{Prosedur Pengumpulan Data}

Prosedur pengumpulan data yang digunakan dalam penelitian ini terdiri dari:

\section{Studi Dokumentasi}

Peneliti melakukan observasi pada objek penelitian dengan tujuan untuk memperoleh data kuantitatif yaitu dengan mengumpulkan data laporan keuangan dan tahunan perusahaan manufaktur sektor industri consumer non-cyclicals subsektor makanan dan minuman yang terdaftar di situs resmi Bursa Efek Indonesia yang beralamat www.idx.co.id periode 2016-2019.

\section{Studi Pustaka}

Peneliti menghimpun data informasi dan teori yang relevan dengan masalah yang menjadi objek penelitian yang diperoleh dari studi pustaka seperti artikel, jurnal, buku dan sumber lain yang relevan dengan masalah penelitian.

\section{Pengolahan dan Analisis Data}

Pada bagian ini penelitian akan menganalisa dan mengolah data yang didapatkan dari sumber data penelitian yaitu laporan keuangan dan tahunan perusahaan manufaktur sektor industri consumer non-cyclicals subsektor makanan dan minuman selama periode 2016-2019 menggunakan perangkat lunak statistic SPSS 24. Analisa data yang digunakan menggunakan statistik deskriptif, koefisien korelasi, koefisien determinasi, uji asumsi klasik, analisis jalur, uji $\mathrm{F}$, uji $\mathrm{t}$ dan analisa regresi berganda. 


\section{Hasil dan Pembahasan}

\section{Analisis Statistik Deskriptif}

\begin{tabular}{|l|r|r|r|r|c|}
\hline \multicolumn{7}{|c|}{ Descriptive Statistics } \\
\hline & $N$ & Minimum & Maximum & \multicolumn{1}{c|}{ Mean } & $\begin{array}{c}\text { Std. } \\
\text { Deviation }\end{array}$ \\
\hline ETR & 40 & 0.1264 & 0.5598 & 0.265413 & 0.0676042 \\
\hline DER & 40 & 0.1635 & 2.2083 & 0.854833 & 0.5825154 \\
\hline SIZE & 40 & 11.5168 & 13.5878 & 12.570795 & 0.6868153 \\
\hline COD & 40 & 0.0031 & 0.2234 & 0.096300 & 0.0557870 \\
\hline Valid N & 40 & & & & \\
(listwise) & & & & & \\
\hline
\end{tabular}

Sumber: Data yang diolah, 2021

Berdasarkan tabel analisa statistik deskripsi diatas dapat diketahui bahwa variabel tax avoidance (ETR) nilai rata-ratanya sebesar 0,265413. Nilai standar deviasi sebesar 0,0676042. Nilai minimum sebesar 0.1264 dari PT Wilmar Cahaya Indonesia Tbk pada tahun 2016 dan nilai maksimum sebesar 0,5598 dari PT Dharma Satya Nusantara Tbk pada tahun 2016. Sedangkan variabel leverage (DER) nilai rata-ratanya sebesar 0, 854833. Nilai standar deviasi sebesar 0,5825154. Nilai minimum sebesar 0,1635 dari PT Ultrajaya Milk Industry \& Trading Company Tbk pada tahun 2018 dan nilai maksimum sebesar 2,2083 dari PT Dharma Satya Nusantara Tbk pada tahun 2018. Terkait variabel ukuran perusahaan (SIZE) nilai rataratanya sebesar 12,570795 . Nilai standar deviasi sebesar 0,6868153 . Nilai minimum sebesar 11,5168 dari PT Dharma Samudera Fishing Industries Tbk pada tahun 2016 dan nilai maksimum sebesar 13,5878 dari PT Indofood CBP Sukses Makmur Tbk pada tahun 2019. Dan terkait variabel cost of debt (COD) nilai rata-ratanya sebesar 0,096300. Nilai standar deviasi sebesar 0,0557870. Nilai minimum sebesar 0,0031 dari PT Ultrajaya Milk Industry \& Trading Company Tbk pada tahun 2017 dan nilai maksimum sebesar 0,2234 dari PT Sariguna Primatirta Tbk pada tahun 2018.

Untuk uji asumsi klasik, penulis melakukan dua tahap dimana substruktur I untuk menguji variabel tax avoidance (ETR) dan leverage (DER) terhadap ukuran perusahaan (SIZE) dan substruktur II untuk menguji variabel tax avoidance (ETR), leverage (DER) dan ukuran perusahaan (SIZE) terhadap cost of debt (COD). 


\section{Uji Asumsi Klasik}

\section{Uji Normalitas Substruktur I}

\begin{tabular}{|c|c|}
\hline \multicolumn{2}{|c|}{ One-Sample Kolmogorov- } \\
\hline & $\begin{array}{l}\text { Unstandardi } \\
\text { zed } \\
\text { Residual }\end{array}$ \\
\hline $\mathrm{N}$ & 40 \\
\hline Normal & 0.0000000 \\
\hline $\begin{array}{ll}\text { Parameter } & \text { Std. } \\
\mathrm{s}^{\mathrm{a}, \mathrm{b}} & \text { Deviation }\end{array}$ & 0.09061995 \\
\hline Absolute & 0.133 \\
\hline Extreme Positive & 0.133 \\
\hline Difference Negative & -0.115 \\
\hline $\begin{array}{l}\text { S } \\
\text { Test Statistic }\end{array}$ & 0.133 \\
\hline Asymp. Sig. (2-tailed) & $.072^{c}$ \\
\hline
\end{tabular}

Sumber: data yang diolah, 2021

Berdasarkan uji normalitas substruktur I dapat diketahui bahwa koefisien Asymp. Sig (2tailed) sebesar 0,072 yang menunjukkan bahwa data yang digunakan pada substruktur I adalah berdistribusi normal karena 0,072 lebih besar dari 0,05.

\section{Uji Normalitas Substruktur II}

\begin{tabular}{|c|c|}
\hline \multicolumn{2}{|c|}{ One-Sample Kolmogorov- } \\
\hline & $\begin{array}{l}\text { Unstandardi } \\
\text { zed } \\
\text { Residual }\end{array}$ \\
\hline $\mathrm{N}$ & 40 \\
\hline Normal & 0.0000000 \\
\hline Parameter Std. & 0.09805729 \\
\hline Absolute & 0.077 \\
\hline Extreme Positive & 0.077 \\
\hline Difference Negative & -0.062 \\
\hline $\begin{array}{l}\text { S } \\
\text { Test Statistic }\end{array}$ & 0.077 \\
\hline Asymp. Sig. (2-tailed) & $.200^{\mathrm{c}, \mathrm{d}}$ \\
\hline
\end{tabular}

Sumber: data yang diolah, 2021

Berdasarkan tabel uji normalitas II dapat diketahui bahwa koefisien Asymp. Sig (2-tailed) sebesar 0,200 yang menunjukkan bahwa data yang digunakan pada substruktur II adalah berdistribusi normal karena 0,200 lebih besar dari 0,05.

\section{Uji Multikolinearitas Substruktur I}

\begin{tabular}{|ll|r|r|}
\hline \multirow{2}{*}{ Model } & \multicolumn{2}{|c|}{ Collinearity Statistics } \\
\cline { 3 - 4 } & & Tolerance & \multicolumn{1}{c|}{ VIF } \\
\hline 1 & (Constant) & & \\
& & & \\
\cline { 3 - 4 } ETR & 0.917 & 1.091 \\
& DER & 0.917 & 1.091 \\
\hline
\end{tabular}


Berdasarkan tabel uji multikolinearitas substruktur I dapat diketahui bahwa variabel tax avoidance (ETR) dan leverage (DER) memiliki nilai tolerance sebesar 0,917 yang lebih besar dari 0,10 dan variabel tax avoidance (ETR) dan variabel leverage (DER) memiliki VIF sebesar 1,091 yang lebih kecil dari 10 sehingga dapat disimpulkan bahwa data yang digunakan pada substruktur I tidak ada multikolinearitas.

\section{Uji Multikolinearitas Substruktur II}

\begin{tabular}{|ll|r|r|}
\hline \multirow{2}{*}{ Model } & & \multicolumn{2}{|c|}{ Collinearity Statistics } \\
\cline { 3 - 4 } & & Tolerance & \multicolumn{1}{c|}{ VIF } \\
\hline 1 & (Constant) & & \\
& & & \\
& ETR & 0.800 & 1.250 \\
& DER & 0.907 & 1.102 \\
& SIZE & 0.873 & 1.146 \\
\hline
\end{tabular}

Sumber: data yang diolah, 2021

Berdasarkan tabel uji multikolinearitas substruktur II dapat diketahui bahwa variabel tax avoidance (ETR) memiliki nilai tolerance sebesar 0,800 yang lebih besar dari 0,1 dan VIF sebesar 1,250 yang lebih kecil dari 10. Terkait variabel leverage (DER) memiliki nilai tolerance sebesar 0,907 yang lebih besar dari 0,1 dan VIF sebesar 1,102 yang lebih kecil dari 10. Dan terkait ukuran perusahaan memiliki nilai tolerance sebesar 0,873 yang lebih besar dari 0,1 dan VIF sebesar 1,146 yang lebih kecil dari 10 sehingga dapat disimpulkan bahwa data yang digunakan pada substruktur II tidak ada multikolinearitas.

\section{Uji Heteroskedastisitas Substruktur I}

\begin{tabular}{|c|c|c|c|c|c|c|}
\hline \multicolumn{7}{|c|}{ Coefficients $^{\mathrm{a}}$} \\
\hline \multirow[b]{2}{*}{ Mode } & & \multicolumn{2}{|c|}{$\begin{array}{l}\text { Unstandardized } \\
\text { Coefficients }\end{array}$} & $\left|\begin{array}{c}\text { Standardiz } \\
\text { ed } \\
\text { Coefficient } \\
\text { s }\end{array}\right|$ & \multirow[b]{2}{*}{$\mathrm{t}$} & \multirow[b]{2}{*}{ Sig. } \\
\hline & & B & Std. Error & Beta & & \\
\hline 1 & (Constant) & $8.414 \mathrm{E}-16$ & 0.127 & & 0.000 & 1.000 \\
\hline & ETR & 0.000 & 0.257 & 0.000 & 0.000 & 1.000 \\
\hline & DER & 0.000 & 0.049 & 0.000 & 0.000 & 1.000 \\
\hline
\end{tabular}

Sumber: data yang diolah, 2021

Berdasarkan tabel uji heteroskedastisitas substruktur I dapat diketahui bahwa nilai signifikansi dari variabel tax avoidance (ETR) dan leverage (DER) sebesar 1,000 yang menunjukkan angka lebih besar dari 0,05 sehingga dapat disimpulkan bahwa data yang digunakan pada substruktur I tidak terjadi heteroskedastisitas. 


\section{Uji Heteroskedastisitas Substruktur II}

\begin{tabular}{|c|c|c|c|c|c|c|}
\hline \multicolumn{7}{|c|}{ Coefficients $^{a}$} \\
\hline \multirow[b]{2}{*}{ Model } & & \multicolumn{2}{|c|}{$\begin{array}{l}\text { Unstandardized } \\
\text { Coefficients }\end{array}$} & \multirow{2}{*}{$\begin{array}{c}\text { Standardiz } \\
\text { ed } \\
\text { Coefficient } \\
\text { s } \\
\text { Beta }\end{array}$} & \multirow[b]{2}{*}{$t$} & \multirow[b]{2}{*}{ Sig. } \\
\hline & & B & Std. Error & & & \\
\hline 1 & (Constant) & $4.080 \mathrm{E}-16$ & 0.605 & & 0.000 & 1.000 \\
\hline & ETR & 0.000 & 0.302 & 0.000 & 0.000 & 1.000 \\
\hline & DER & 0.000 & 0.054 & 0.000 & 0.000 & 1.000 \\
\hline & SIZE & 0.000 & 0.180 & 0.000 & 0.000 & 1.000 \\
\hline
\end{tabular}

Sumber: data yang diolah, 2021

Berdasarkan tabel uji heteroskedastisitas substruktur II dapat diketahui bahwa nilai signifikansi variabel tax avoidance (ETR), leverage (DER) dan ukuran perusahaan (SIZE) sebesar 1,000 yang menunjukkan angka lebih besar dari 0,05 sehingga dapat disimpulkan bahwa data yang digunakan pada substruktur II tidak terjadi heteroskedastisitas.

\section{Uji Autokorelasi Substruktur I}

\begin{tabular}{|c|c|c|c|c|c|}
\hline \multicolumn{6}{|c|}{ Model Summary } \\
\hline Model & $\mathrm{R}$ & R Square & $\begin{array}{l}\text { Adjusted R } \\
\text { Square }\end{array}$ & $\begin{array}{l}\text { Std. Error of } \\
\text { the Estimate }\end{array}$ & $\begin{array}{l}\text { Durbin- } \\
\text { Watson }\end{array}$ \\
\hline 1 & $.361^{\mathrm{a}}$ & .130 & .083 & .09334 & 1.549 \\
\hline
\end{tabular}

Sumber: data yang diolah 2021

Berdasarkan tabel uji autokorelasi substruktur I dapat diketahui bahwa Durbin-Watson sebesar 1,549 dengan jumlah data sebanyak 40 dan jumlah variabel eksogen $(k=2)$, maka $\boldsymbol{d}_{\boldsymbol{L}}=\mathbf{1}, \mathbf{4 4 2 1 4}$ dan $\boldsymbol{d}_{\boldsymbol{u}}=\mathbf{1}, \mathbf{5 4 4 3 6}$. Maka dapat disimpulkan bahwa data yang digunakan pada substruktur I tidak terdapat autokorelasi karena nilai Durbin-Watson substruktur I sebesar 1,549 lebih besar dari nilai $\boldsymbol{d}_{\boldsymbol{u}}=\mathbf{1 , 5 4 4 3 6}$ dan lebih kecil dari nilai $\mathbf{4}-\boldsymbol{d}_{\boldsymbol{u}}=$ 2,45564 .

\section{Uji Autokorelasi Substruktur II}

\begin{tabular}{|c|c|c|c|c|c|}
\hline \multicolumn{6}{|c|}{ Model Summary } \\
\hline Model & $\mathrm{R}$ & R Square & $\begin{array}{c}\text { Adjusted R } \\
\text { Square }\end{array}$ & $\begin{array}{l}\text { Std. Error of } \\
\text { the Estimate }\end{array}$ & $\begin{array}{l}\text { Durbin- } \\
\text { Watson }\end{array}$ \\
\hline 1 & $.482^{\mathrm{a}}$ & .232 & .168 & .10234 & 1.745 \\
\hline
\end{tabular}

Sumber: data yang diolah, 2021

Berdasarkan tabel uji autokorelasi substruktur II dapat diketahui bahwa Durbin-Watson sebesar 1,745 dengan jumlah data sebanyak 40 dan jumlah variabel eksogen $(k=3)$, maka 
$\boldsymbol{d}_{\boldsymbol{L}}=\mathbf{1}, \mathbf{3 9 3 0 8 3}$ dan $\boldsymbol{d}_{\boldsymbol{u}}=\mathbf{1}, \mathbf{5 9 9 9 9}$. Maka dapat disimpulkan bahwa data yang digunakan pada substruktur II tidak terdapat autokorelasi karena nilai Durbin-Watson substruktur II sebesar 1,745 lebih besar dari nilai $\boldsymbol{d}_{\boldsymbol{u}}=\mathbf{1 , 5 9 9 9 9}$ dan lebih kecil dari nilai $\mathbf{4}-\boldsymbol{d}_{\boldsymbol{u}}=$ 2,40001 .

\section{Analisis Jalur (Path Analysis)}

Analisis ini digunakan untuk menganalisa hubungan antara variabel bebas dengan variabel terikat dengan tujuan untuk mengetahui pengaruh langsung atau tidaknya (Riduwan \& Kuncoro, 2011).

\section{Uji Signifikan F (Testing Hypothesis the Whole Model)}

\section{Substruktur I}

\begin{tabular}{|c|c|c|c|c|c|c|}
\hline \multicolumn{7}{|c|}{ ANOVA $^{a}$} \\
\hline Model & & $\begin{array}{l}\text { Sum of } \\
\text { Squares }\end{array}$ & df & Mean Square & $\mathrm{F}$ & Sig. \\
\hline \multirow[t]{3}{*}{1} & Regression & .048 & 2 & .024 & 2.776 & $.075^{b}$ \\
\hline & Residual & .322 & 37 & .009 & & \\
\hline & Total & .371 & 39 & & & \\
\hline
\end{tabular}

Sumber: data yang diolah, 2021

\section{Substruktur II}

\begin{tabular}{|c|c|c|c|c|c|c|}
\hline \multicolumn{7}{|c|}{ ANOVA $^{a}$} \\
\hline Model & & $\begin{array}{l}\text { Sum of } \\
\text { Squares }\end{array}$ & df & Mean Square & $\mathrm{F}$ & Sig. \\
\hline \multirow[t]{3}{*}{1} & Regression & .114 & 3 & .038 & 3.623 & $.022^{\mathrm{b}}$ \\
\hline & Residual & .377 & 36 & .010 & & \\
\hline & Total & .491 & 39 & & & \\
\hline
\end{tabular}

Sumber: data yang diolah, 2021

Berdasarkan tabel uji signifikan F substruktur I dapat diketahui bahwa ETR dan DER tidak berpengaruh signifikan terhadap SIZE karena nilai $F_{\text {hitung }}$ 2,776 lebih kecil dari $F_{\text {tabel }} 3,24$ dengan tingkat signifikansi 0,075 lebih besar dari 0,05. Sedangkan tabel uji signifikan F substruktur II dapat diketahui bahwa ETR, DER dan SIZE secara signifikan berpengaruh terhadap COD karena nilai $F_{\text {hitung }} 3,623$ lebih besar dari $F_{\text {tabel }} 2,86$ dengan tingkat signifikansi 0.022 lebih besar dari 0,05. 


\section{Uji Signifikan t (Testing Hypothesis Slope)}

\section{Substruktur I}

\begin{tabular}{|c|c|c|c|c|c|c|}
\hline \multicolumn{7}{|c|}{ Coefficients $^{a}$} \\
\hline & & \multicolumn{2}{|c|}{ Unstandardized Coefficients } & \multirow{2}{*}{$\begin{array}{c}\text { Standardized } \\
\text { Coefficients } \\
\text { Beta }\end{array}$} & \multirow[b]{2}{*}{$\mathrm{t}$} & \multirow[b]{2}{*}{ Sig. } \\
\hline & & $B$ & Std. Error & & & \\
\hline \multirow[t]{3}{*}{1} & (Constant) & 3.259 & .128 & & 25.542 & .000 \\
\hline & ETR & .609 & .258 & .377 & 2.356 & .024 \\
\hline & DER & -.030 & .049 & -.100 & -.623 & .537 \\
\hline
\end{tabular}

a. Dependent Variable: SIZE

Sumber: data yang diolah, 2021

\section{Substruktur II}

\begin{tabular}{|c|c|c|c|c|c|c|}
\hline \multicolumn{7}{|c|}{ Coefficients $^{a}$} \\
\hline & & \multicolumn{2}{|c|}{ Unstandardized Coefficients } & \multirow{2}{*}{$\begin{array}{c}\text { Standardized } \\
\text { Coefficients } \\
\text { Beta }\end{array}$} & \multirow[b]{2}{*}{$t$} & \multirow[b]{2}{*}{ Sig. } \\
\hline Model & & $\mathrm{B}$ & Std. Error & & & \\
\hline \multirow[t]{4}{*}{1} & (Constant) & 1.249 & .604 & & 2.068 & .046 \\
\hline & ETR & -.226 & .304 & -.121 & -.743 & .462 \\
\hline & DER & .145 & .054 & .413 & 2.696 & .011 \\
\hline & SIZE & -.274 & .180 & -.238 & -1.518 & .138 \\
\hline
\end{tabular}

Sumber: data yang diolah, 2021

Berdasarkan tabel uji signifikan $\mathrm{t}$ substruktur I dapat diketahui bahwa nilai signikansi ETR sebesar 0,024 lebih kecil dari 0,05 dan nilai $t_{\text {hitung }} 2,356$ lebih besar dari $t_{\text {tabel }} 2,0269$ yang membuktikan bahwa terdapat pengaruh yang signifikan antara ETR terhadap SIZE. Sedangkan nilai signifikansi DER sebesar 0,537 lebih besar dari 0,05 dan nilai $t_{\text {hitung }}-0,623$ lebih kecil dari $t_{\text {tabel }} 2,02619$ yang membuktikan tidak ada pengaruh antara DER terhadap SIZE. Terkait tabel uji signifikan $\mathrm{t}$ substruktur II dapat diketahui bahwa nilai signifikansi ETR sebesar 0,462 lebih besar dari 0,05 dengan nilai $t_{\text {hitung }}-0,743$ lebih kecil dari $t_{\text {tabel }} 2,02809$ yang membuktikan tidak ada pengaruh antara ETR terhadap COD. Sedangkan nilai signikansi DER sebesar 0,011 lebih kecil dari 0,05 dengan nilai $t_{\text {hitung }}$ 2,696 lebih besar dari $t_{\text {tabel }} 2,02809$ yang membuktikan ada pengaruh antara DER terhadap COD. Dan untuk nilai signifikansi SIZE sebesar 0,138 lebih besar dari 0,05 dengan nilai $t_{\text {hitung }}-$ 1,518 lebih kecil dari $t_{\text {tabel }}$ 2,02809 yang membuktikan tidak ada pengaruh antara SIZE terhadap COD. 


\section{Analisa Regresi Berganda}

\section{Struktur I}

$Y_{1}=\beta_{1} X_{1}+\beta_{2} X_{2}+e_{1}$

$Y_{1}=0,377 X_{1}-0,100 X_{2}+0,9327 e_{1}$

$e_{1}=\sqrt{1-R^{2}}$

$e_{1}=\sqrt{1-0,130}=0,9327$

\section{Struktur II}

$Y_{2}=\beta_{3} X_{1}+\beta_{4} X_{2}+\beta_{5} Y_{1}+e_{2}$

$Y_{2}=-0,121 X_{1}+0,413 X_{2}-0,238 Y_{1}+0,8764 e_{2}$

$e_{2}=\sqrt{1-R^{2}}$

$e_{2}=\sqrt{1-0,232}=0,8764$

\section{Koefisien Determinasi Total}

$R_{m}^{2}=1-\left(e_{1}^{2}\right) x\left(e_{2}^{2}\right)$

$R_{m}^{2}=1-\left(0,9327^{2}\right) x\left(0,8764^{2}\right)=0,3318$

Berdasarkan hasil perhitungan koefisien determinasi total menunjukkan bahwa variasi data yang dipengaruhi oleh model sebesar $33,18 \%$ dapat dijelaskan oleh model dan sisanya $66,82 \%$ dijelaskan oleh variabel lain diluar model.

\section{Pembahasan}

Melalui hasil pembahasan dan pengujian dari penelitian mediasi ukuran perusahaan antara tax avoidance dan leverage terhadap cost of debt, maka dapat disimpulkan sebagai berikut,

\section{Pengaruh Tax Avoidance dan Leverage Terhadap Ukuran Perusahaan}

Variabel antara Tax Avoidance (ETR) dan Leverage (DER) tidak berpengaruh signifikan terhadap SIZE karena nilai $F_{\text {hitung }} 2,776$ lebih kecil dari $F_{\text {tabel }} 3,24$ dengan tingkat signifikansi 0,075 lebih besar dari 0,05.

\section{Pengaruh Tax Avoidance, Leverage dan Ukuran Perusahaan Terhadap Cost Of Debt}

Variabel antara Tax Avoidance (ETR), Leverage (DER) dan Ukuran Perusahaan (SIZE) secara signifikan berpengaruh terhadap COD karena nilai $F_{\text {hitung }} 3,623$ lebih besar dari $F_{\text {tabel }} 2,86$ dengan tingkat signifikansi 0.022 lebih besar dari 0,05.

Pengaruh Tax Avoidance Terhadap Cost Of Debt Dengan Ukuran Perusahaan Sebagai Variabel Mediasi

Diketahui pengaruh langsung antara Tax Avoidance (ETR) terhadap Cost Of Debt (COD) sebesar -0,121 sedangkan pengaruh tidak langsung Tax Avoidance (ETR) melalui Ukuran Perusahaan (SIZE) terhadap Cost Of Debt (COD) sebesar -0,0897. Berdasarkan perhitungan ini dapat disimpulkan bahwa secara tidak langsung Tax Avoidance (ETR) melalui Ukuran 
Perusahaan (SIZE) tidak berpengaruh signifikan terhadap Cost Of Debt (COD) karena nilai pengaruh secara tidak langsung lebih kecil daripada pengaruh secara langsung.

\section{Pengaruh Leverage Terhadap Cost Of Debt Dengan Ukuran Perusahaan Sebagai Variabel Mediasi}

Diketahui pengaruh langsung antara Leverage (DER) terhadap Cost Of Debt (COD) sebesar 0,413 sedangkan pengaruh tidak langsung Leverage (DER) melalui Ukuran Perusahaan (SIZE) terhadap Cost Of Debt (COD) sebesar 0,0238. Berdasarkan perhitungan ini dapat disimpulkan bahwa secara tidak langsung Leverage (DER) melalui Ukuran Perusahaan (SIZE) tidak berpengaruh signifikan terhadap Cost Of Debt (COD) karena nilai pengaruh secara tidak langsung lebih kecil daripada pengaruh secara langsung.

\section{Penutup dan Saran}

Melalui pembahasan hasil pengujian dan kesimpulan diatas terkait penelitian mediasi ukuran perusahaan antara tax avoidance dan leverage terhadap cost of debt, maka saran yang penulis dapat sampaikan sebagai berikut: 1.) Saran bagi perusahaan manufaktur sektor industri consumer non-cyclicals subsektor makanan dan minuman untuk dapat lebih memperhatikan Tax Avoidance, Leverage dan Ukuran Perusahaan karena berpengaruh terhadap Cost Of Debt; 2.)Saran bagi peneliti terkait selanjutnya untuk dapat menambahkan variabel bebas selain Tax Avoidance, Leverage dan Ukuran Perusahaan karena 66,82\% dijelaskan oleh variabel lain diluar model.

\section{Referensi}

Ashkhabi, I. R., \& Agustina, L. (2015). Pengaruh Corporate Governance, Struktur Kepemilikan perusahaan dan Ukuran Perusahaan terhadap Biaya Utang. Accounting Analysis Journal, 4(3), 1-8.

Azizah, K. (2016). Pengaruh Penghindaran Pajak Terhadap Biaya Hutang Dengan Kepemilikan Institusional Sebagai Variabel Moderasi Pada Perusahaan Manufaktur Yang Terdaftar Di Bursa Efek Indonesia Periode 2013-2015. Skripsi. Universitas Airlangga.

Cooper, D. R., \& Schindler, P. (2013). Business Research Methods 12 th Edition. New York: McGraw- Hill Higher Education.

Damayanti, A. (2020). 10 Ritel Raksasa yang Bangkrut di 2020 Gara-gara Corona. https:/ finance.detik.com/berita-ekonomi-bisnis/d-5312096/10-ritel-raksasa-yangbangkrut-di-2020-gara-gara-corona

Dewi, A. A. A. K., \& Badjra, I. B. (2017). Pengaruh Profitabilitas, Aktiva Tidak Berwujud, Ukuran Perusahaan, dan Struktur Modal Terhadap Nilai Perusahaan. E-Jurnal Manajemen, 6(4), 2161-2190.

Ernawati, D \& Widyawati, D. (2015). Pengaruh Profitabilitas, Leverage Dan Ukuran Perusahaan Terhadap Nilai Perusahaan. Jurnal Ilmu \& Riset Akuntansi, 4(4). 
Fitriani, S.A. (2017). Pengaruh Penghindaran Pajak (Tax Avoidance) Terhadap Biaya Utang Pada Perusahaan Manufaktur Yang Terdaftar Di Bursa Efek Indonesia. Skripsi. Universitas Sumatera Utara.

Handini, S. (2020). Manajemen Keuangan. Surabaya: Scopindo Media Pustaka.

Hanlon, M., \& Heitzman, S. (2010). A review of tax research. Journal of accounting and Economics, 50(2-3), 127-178.

Hidayat, W. W. (2018). Pengaruh profitabilitas, leverage dan pertumbuhan penjualan terhadap penghindaran pajak. Jurnal Riset Manajemen dan Bisnis (JRMB) Fakultas Ekonomi UNIAT, 3(1), 19-26.

Isroah, I. (2013). Perpajakan. Yogyakarta: Penerbit Universitas Negeri Yogyakarta.

Kholbadalov, U. (2012). The relationship of corporate tax avoidance, cost of debt and institutional ownership: evidence from Malaysia. Atlantic Review of Economics: Revista Atlántica de Economía, 2(1), 7-36.

Lim, Y. (2011). Tax avoidance, cost of debt and shareholder activism: Evidence from Korea. Journal of Banking \& Finance, 35(2), 456-470.

Mahi, A. K. (2016). Pengembangan Wilayah: Teori Dan Aplikasi. Jakarta: Kencana.

Manik, S. J., Sianipar, I. D. S., \& Yunanto, M. (2015). Manajemen Keuangan. Depok: Universitas Gunadarma.

Meyer, S. (2020). Gila! COVID-19 Bikin Utang Perusahaan Dunia Capai Empat Belas Ribu Trilyun Rupiah. CNBC online Jul 2020 Diperoleh dari: https:// www.cnbcindonesia.com/market/20200713165237-17-172322/ gila-covid-19bikin-utang-perusahaan-dunia-capai-rp-14000-t

Prasetyo, A. H. (2019). Bentoel Didera Rugi Menahun Hingga Tudingan Memanfaatkan Celah Pajak Dan Cukai. https://insight.kontan.co.id/news/bentoel-didera-rugi-menahunhingga-tudingan-memanfaatkan-celah-pajak-dan-cukai

Pratama, I. G. B. A., \& Wiksuana, I. G. B. (2016). Pengaruh ukuran perusahaan dan leverage terhadap nilai perusahaan dengan profitabilitas sebagai variabel mediasi. E-Jurnal Manajemen, 5(2), 1338-1367.

Purwanti, N. (2016). Pengaruh penghindaran pajak terhadap biaya hutang pasca perubahan tarif pajak badan pada perusahaan manufaktur yang terdaftar di bursa efek indonesia. Jurnal Akuntansi Indonesia, 3(2), 113-128.

Rahmawati, A. (2017). Pengaruh Profitabilitas, Ukuran Dewan Pengawas Syariah Dan Ukuran Perusahaan Terhadap Pembayaran Zakat: Studi Kasus Pada Bank Umum Syariah Di Indonesia Periode 2010-2015. Skripsi. Universitas Islam Negeri Maulana Malik Ibrahim Malang.

Riduwan \& Kuncoro, E. A. (2011). Cara Menggunakan dan Memakai Analisis Jalur (Path Analysis). Cetakan Ketiga. Bandung: Alfabeta. 
Rika, H. (2019, Juli 24). Kredit Bank Dan Utang Jadi Sumber Pendanaan Ekonomi RI. https:// m.cnnindonesia.com/ekonomi/20190724153416-532-415118/kredit-bank-danutang-jadi-sumber-pendanaan-ekonomi-ri

Saputro, R. E. (2018). Pengaruh Tax Avoidance Terhadap Biaya Utang (Cost Of Debt) Dengan Transparansi Perusahaan Sebagai Variabel Moderating (Studi Empiris Pada Perusahaan Manufaktur Yang Terdaftar Di BEI Periode 2013-2017). Skripsi. Universitas Islam Negeri Syarif Hidayatullah.

Sartono, A. (2015). Manajemen Keuangan Teori dan Aplikasi Edisi Lima. Jakarta: Rajawali Pers.

Setiawan, S. R. D. (2020). Terimbas Virus Corona, Peritel Berusia 202 Tahun Bangkrut. https://money.kompas.com/read/2020/07/10/052100726/terimbas-virus-coronaperitel-berusia-202-tahun-bangkrut

Sherly, E. N., \& Fitria, D. (2019). Pengaruh Penghindaran Pajak, Kepemilikan Institusional, dan Profitabilitas Terhadap Biaya Hutang (Studi Empiris Pada Perusahaan Manufaktur Yang Terdaftar Di BEI Periode 2011-2015). EKOMBIS REVIEW: Jurnal Ilmiah Ekonomi dan Bisnis, 7(1), 58-69.

Subroto, B. (2014). Pengungkapan Wajib Perusahaan Publik: Kajian Teori Dan Empiris. Malang: Universitas Brawijaya Press.

Suwardika, I. N. A., \& Mustanda, I. K. (2017). Pengaruh leverage, ukuran perusahaan, pertumbuhan perusahaan, dan profitabilitas terhadap nilai perusahaan pada perusahaan properti. E-jurnal Manajemen, 6(3), 1248-1277.

Swissia, P \& Purba, B. (2018). Pengaruh Struktur Kepemilikan Institusional, Kepemilikan Manajerial, Kepemilikan Keluarga, Pengungkapan Sukarela Dan Leverage Terhadap Biaya Utang. JURNAL Akuntansi \& Keuangan, 9(2), 42-65.

Utama, F., Kirana, D. J., \& Sitanggang, K. (2019). Pengaruh penghindaran pajak terhadap biaya hutang dan kepemilikan institusional sebagai pemoderasi. Jurnal Bisnis Dan Akuntansi, 21(1), 47-60.

Wardani, S. L., \& Ruslim, H. (2020). Pengaruh Dar, Ukuran Perusahaan, Dan Tax Avoidance Terhadap Cost Of Debt. Jurnal Manajerial Dan Kewirausahaan, 2(2), 469-478.

Yuniartha, L. (2019). Penerimaan Pajak Industri Manufaktur Turun 16,2\%. Kontan.co.id. https://nasional.kontan.co.id/news/januari-2019-penerimaan-pajak-industrimanufaktur-turun-162.

Zahro, F., Afifudin, A., \& Mawardi, M. C. (2018). Pengaruh Penghindaran Pajak Dan Good Corporate Governance Terhadap Cost Of Debt. E-JRA, 7(6), 62-76. 